\title{
Prevalence of Chest Symptomatics in a Rural Population of Kancheepuram District, South India.
}

\author{
Dinesh Dimri, ${ }^{1}$ Venkatachalam J ${ }^{1}$, Z. Singh ${ }^{2}$, S. Joyce ${ }^{3}$, Anil J purty ${ }^{4}$,Sathya \\ $\mathrm{GR}^{5}$.
}

Assistant Professor ${ }^{l,}$ Department of Community Medicine, PIMS, Pondicherry, India, Professor ${ }^{2,4}$ Department of Community Medicine, PIMS, Pondicherry, India. Assistant Professor ${ }^{3}$, Department of Community Medicine, Dr.Somervel Memorial CSI Medical college, Karakonam, India. Post Graduate ${ }^{5}$ (Physiology), PIMS, Pondicherry.

\begin{abstract}
Background: Tuberculosis is a chronic communicable bacterial disease of ancient origin. It is caused by Mycobacterium tuberculosis, primarily infects the lungs causing pulmonary tuberculosis. TB continues to be a major public health problem worldwide. World Bank has estimated the global burden of TB in terms of DALYs loss and stated that tuberculosis stands $7^{\text {th }}$ in the ten leading causes of global DALYs loss and expected to maintain its position even in 2010 AD. Because of its severity and consequences, in 1993, WHO has declared TB as a "global emergency".

Premature death is the main cause of the burden of TB, as measured in terms of DALYs lost. Besides the disease burden, TB also causes an enormous socio-economic burden to India. TB primarily affects people in their most productive years of life with important socio-economic consequences for the household and the disease is even more common among the poorest and marginalized sections of the community. Almost $70 \%$ of $T B$ patients are aged between the ages 15 and 54 years of age. So this study was planned to know about prevalence of chest symptomatics in study population.

Material and Methods:A cross sectional study was carried out in Kancheepuram, a district belonging to the field practice area of Rural Health training Centre-Chunampet, Department of Community Medicine, Pondicherry Institute of Medical Sciences. House to house survey was done for selection of the study respondent. The study was carried out in from the month of Feb-April, 2012. About 2005 adults were interviewed by using a pretested validated questionnaire. Data entry and analysis was done using SPSS 16.0.

Result: Total of 2005 respondents were interviewed out of which 1196(59.7\%) were females and remaining 809 (40.35) were males. Maximum (35.3\%) respondents belonged to the age group of 15-30 years followed by 31-35 years age group $(28.7 \%)$. Out of the 2005 study population majority, 1474(73.5\%) had no ailments whereas, $277(13.8 \%)$ suffered from associated symptoms like hemoptysis, chest pain, Breathlessness, loss of appetite and decreased energy levels despite adequate rest. However, 254(12.7\%) were found with one or more symptoms suggestive of TB. When the symptoms suggestive of TB was considered, 181(9.0\%) of the study respondents had cough for more than 2 weeks, 91(4.5\%) had loss of weight, 57(2.8\%) and 49(2.4\%) had fever for more than 2 weeks and night sweats respectively.
\end{abstract}

Conclusion: prevalence of suspected tuberculosis patient was high in the community. Key words:Tuberculosis, prevalence, rural area,

\section{Introduction}

Tuberculosis is a chronic communicable bacterial disease of ancient origin. It is caused by Mycobacterium tuberculosis, primarily infects the lungs causing pulmonary tuberculosis. TB continues to be a major public health problem worldwide. World Bank has estimated the global burden of TB in terms of DALYs loss and stated that tuberculosis stands $7^{\text {th }}$ in the ten leading causes of global DALYs loss and expected to maintain its position even in 2010 AD. Because of its severity and consequences, in 1993, WHO has declared TB as a "global emergency". In 2008, there were estimated 9.4 million new cases equivalents to 139 cases per $1,00,000$ population of TB globally. ${ }^{1}$ The South East Asia region accounts for $34 \%$ of the global TB burden. ${ }^{2}$ Though India is the second-most populous country in the world, India has more new TB cases annually than any other country. TB is one of the leading cause of mortality in India killing 2 persons every three minute, nearly 1,000 every day. ${ }^{4}$ With increasing prevalence of HIV infection the problem of TB is likely to be compounded in the years to come. ${ }^{5}$ Premature death is the main cause of the burden of TB, as measured in terms of DALYs lost. Besides the disease burden, TB also causes an enormous socio-economic burden to India. TB primarily affects people in their most productive years of life with important socio-economic consequences for the household and the disease is even more common among the poorest and marginalized sections of the community. Almost $70 \%$ of TB patients are aged between the ages 15 and 54 years of age. While two thirds of the cases are male, TB takes a disproportionately larger toll among young females, with more than $50 \%$ of female cases occurring 
before 34 years of age. TB deaths among women have major implications for child survival and family welfare. The social stigma of the disease adds to the burden for both men and women. The direct and indirect cost of TB to India amounts to an estimated $\$ 3$ billion annually. ${ }^{6}$ Tuberculosis being more prevalent among the rural population and since there were very few studies regarding the prevalence of chest symptomatics in Tamil Nadu, this study was planned to study the prevalence of chest symptomatics among the people in Rural areas of Kancheepuram district, Tamil Nadu.

\section{Material and Methods}

Community based cross sectional study was carried out by house to house survey method in six villages of Kancheepuram district belonging to the field practice area of Chunampet Rural Health Training Centre of Department of Community Medicine, Pondicherry Institute of Medical Sciences, Pondicherry. The study was carried out from Feb-April, 2012. All individuals above the age of 18 years who were included in the study. The purpose of the study was explained to the study participants and informed consent was obtained. Data were collected by group of pre final year students, interns, post graduates and supervised by faculties from Dept of Community Medicine, using a pretested, predesigned, questionnaire by personal interview method. Data entry and analysis was done using SPSS version 16.0

\section{Results}

A total of 2005 respondents were interviewed, $1196(59.7 \%)$ were females and $809(40.3 \%)$ were males. Maximum respondents belonged to the age group of 15 - 30 years (35.3\%), followed by $31-45$ years age group (28.7\%). 1567(78.2\%) were married and 1185(59.1\%) were living in overcrowded houses . 691 $(34.5 \%)$ of them were illiterates and only $233(11.6 \%)$ were educated till higher secondary \& above. With respect to occupation $904(45.1 \%)$ were doing business followed by 838 (41.8\%) who were daily wagers. A total of $1343(67 \%)$ belonged to Class 4 \& 5 Socio Economic Class as per modified BG Prasad classification. Out of the 2005 study respondents, 606(30.2\%), 710(35.4\%) and 689(34.4\%), lived in Kutcha, semi-pucca and pucca houses respectively. Majority of the respondents $1036(51.7 \%)$ used outdoor kitchen for cooking and most $1458(72.6 \%)$ of them used firewood/coal as the cooking fuel. Only 891(44.4\%) of respondents had a cattle in their house

(Table 1)

Table 1: Socio-economic status of the study respondents ( $\mathrm{N}=\mathbf{2 0 0 5})$

\begin{tabular}{|c|c|}
\hline Characteristic & $\begin{array}{l}\text { Frequency }(\%) \\
\mathrm{N}=2005\end{array}$ \\
\hline Age (years) & \\
\hline $15-30$ & $708(35.3)$ \\
\hline $31-45$ & $574(28.7)$ \\
\hline $46-60$ & $423(21.1)$ \\
\hline $61-75$ & 239 (11.9) \\
\hline $76-90$ & $61 \quad(3.0)$ \\
\hline Gender & \\
\hline Male & 809(40.3) \\
\hline Female & $1196(59.7)$ \\
\hline Education & \\
\hline Illiterate & 691(34.5) \\
\hline Primary school & $213(10.6)$ \\
\hline Secondary school & $350(17.5)$ \\
\hline High school & $518(25.8)$ \\
\hline Higher secondary & $130(6.5)$ \\
\hline Graduate and above & $103(5.1)$ \\
\hline Occupation & \\
\hline Daily wagers & $838(41.8)$ \\
\hline Business & $904(45.1)$ \\
\hline Service & $101(5.0)$ \\
\hline Professionals & $136(6.8)$ \\
\hline Unemployed/Housewives & $26(1.3)$ \\
\hline Socio-economic class & \\
\hline Upper & $88(4.4)$ \\
\hline Upper middle & $217(10.8)$ \\
\hline Lower middle & $357(17.8)$ \\
\hline Upper lower & $652(32.5)$ \\
\hline Lower & $691(34.5)$ \\
\hline Housing pattern & \\
\hline
\end{tabular}




\begin{tabular}{|r|l|}
\hline Kutcha & $606(30.2)$ \\
Semi-pucca & $710(35.4)$ \\
Pucca & $689(34.4)$ \\
\hline Place of cooking & \\
Separate kitchen in the house & $476(23.7)$ \\
Kitchen in living room & $236(11.8)$ \\
Outdoor kitchen & $1036(51.7)$ \\
Separate room built as kitchen & $257(12.8)$ \\
\hline Cooking fuel* & \\
Kerosene & $300(15.0)$ \\
Firewood/coal & $1458(72.6)$ \\
LPG & $632(31.4)$ \\
\hline
\end{tabular}

\section{Spectrum of Symptoms among study respondent}

Out of the 2005 study population majority, 1474(73.5\%) had no ailments whereas, 277(13.8\%) suffered from associated symptoms like hemoptysis, chest pain, Breathlessness, loss of appetite and decreased energy levels despite adequate rest. However, 254(12.7\%) were found with one or more symptoms suggestive of TB.

Table 6: pattern of symptoms and signs with respect to tuberculosis among study respondents $(\mathrm{N}=2005)$

\begin{tabular}{|l|l|}
\hline Characteristic & Frequency $(\%)$ \\
\hline Morbidity pattern & \\
Asymptomatic & $1474(73.5)$ \\
One or more symptoms suggestive of TB & $254(12.7)$ \\
Other associated symptoms & $277(13.8)$ \\
\hline
\end{tabular}

Table 7: Spectrum of chest symptoms among the study respondents $(\mathrm{N}=\mathbf{2 0 0 5})$

When the symptoms suggestive of TB was considered, 181(9.0\%) of the study respondents had cough for more than 2 weeks, $91(4.5 \%)$ had loss of weight, $57(2.8 \%)$ and $49(2.4 \%)$ had fever for more than 2 weeks and night sweats respectively

\begin{tabular}{|r|l|}
\hline Characteristic & $\begin{array}{l}\text { Frequency } \\
(\%)\end{array}$ \\
\hline Symptoms suggestive of TB & \\
Cough (>2 weeks) & $181(9.0)$ \\
Fever (>2 weeks) & $57(2.8)$ \\
Loss of weight (Loss of & $91(4.5)$ \\
appetite) & $49(2.4)$ \\
Night sweats & \\
Other symptoms & $19(0.9)$ \\
Hemoptysis & $136(6.8)$ \\
Chest pain & $171(8.5)$ \\
Breathlessness & $169(8.4)$ \\
Loss of appetite & $272(13.6)$ \\
\hline Decreased energy level & \\
\hline
\end{tabular}

\section{Discussion:}

India was the highest TB burden country with World health Organisation (WHO) statistics for 2010 gave an estimated incidence figure of 2.3 million cases of TB for India, this shows Indian subcontinent contributing about $25 \%$ of total case of tuberculosis in the world. This gives alarming signal to government of India to curtain the burden of TB in our community. The WHO statistics also showed that India was 17th out of the 22 high burden countries in terms of TB incidence rate. The estimated TB prevalence figure for 2010 was given as 3.1 million $^{10}$. Moreover, it was estimated that about $40 \%$ of the Indian population was infected with TB bacteria, the vast majority of whom have latent rather than active $\mathrm{TB}^{11}$. So we need know the impact of national programme like RNTCP. For assessing impact of RNTCP is many methods are available however prevalence of chest symptamatics in study population also indirectly tells about impact of the programme. With respect to Prevalence of chest Symptomatic in our study area is high 9\% compared to other areas where the prevalence is $5.5 \%$ in West Bengal and also similar study finding found in other part of Tamil Nadu were the prevalence is 5.5\% in rural area and 3.9\% urban area. This high prevalence in our study area is due to change in definition of chest symptamatics. As we knew that the revised operational definition for chest symptamatics according to RNTCP guidelines is any person who having cough more than two weeks can be screened for Tuberculosis, which was earlier three weeks. Hence in our study we followed cough more than two weeks as chest 
symptamatics. That was reason for high prevalence. A similar study done in Vietnam also showed that prevalence was as low as $1.6 \%$. This may due to seasonal variation and also variation socio demographic profiles. In addition to chest symptamatics we also analysed other symptoms of tuberculosis, in our study we found that about $.9 \%$ of study population having hemoptysis, $6.8 \%$ had chest pain, $8.5 \%$ of the respondent had breathlessness. With respect to other symptoms of tuberculosis majority of the study population had poor energy $13.6 \%$ followed by breathlessness $171(8.5 \%)$, loss of appetite $169(8.4 \%)$ and $6.8 \%$ of the respondent reported that chest pain. Only $19(0.9 \%)$ of respondent had hemoptysis.

\section{Conclusion:}

The prevalence of suspected tuberculosis was high among this community so proper IEC \&BCC should focus among this population.

\section{Contributions:}

Venkatachalam J: Conception and design of the study; planning and conducting the study; analysis and interpretation of data; and drafting the paper.

Dinesh Dimri : Design of the study; providing guidance; and revising the draft critically for substantial intellectual content.

Zile Singh: Design of the study; and revising the draft critically for substantial intellectual content.

Subha Joice : Design of the study; planning and coordinating the study;

Anil J Purty:- Analysis and interpretation of data; drafting the paper

Sathya GR:- Manuscript revision

Conflict of Interest:- None.

\section{Role of Funding Source:- Pondicherry Institute of Medical Sciences}

\section{Acknowledgements:}

The authors would like to thank, Chairman PIMS Management committee, Director -Principal PIMS, for providing financial and transport support for this study. The authors want to extend thanks to final year part-I MBBS students for helping in data collection and data entry. Also extend thanks to Dr. Subramanium, RMO, Chunampet RHTC, for supervision of data collectin

\section{References}

[1] World Health Organization. Global Tuberculosis Control 2009: Epidemiology, Strategy, Financing. [Online] 2009 [cited on 2010 Feb]; Available from: URL:whqlibdoc.who.int/publications/2009/9789241563802_eng.pdf

[2] Government of India. TB India 2010 RNTCP status report. New Delhi (India), Central TB division MOHFW; 2010. p 1

[3] Government of India. TB India 2010 RNTCP status report. New Delhi (India), Central TB division MOHFW; 2010. p 2

[4] Tuberculosis key facts. [Online] [cited $2012 \mathrm{Feb]}$;Available from: URL:http://www.tbcindia.org/key.asp

[5] Yadav SP, Mathur ML, Dixit AK, Knowledge attitude practises towards TB among sandstone quarry workers in desert parts of Rajasthan, Indian Journal Tubercle 2006; 53:187-195

[6] Kishore J. National health programs of India national policies and legislations related to health. 9th ed. New Delhi (India), Century Publications; 2011.

[7] Sreeparna ghosh, Apurba S,Taraphdar P,Mukhopadhyay DK,Mahapatra, Biwas AB.A study on care seeking behaviour of chest symptamatics in a slum of Bankura,WB.ijph,2010;54:1

[8] Niruparani Charles1*, Beena Thomas1, Basilea Watson1, Raja Sakthivel M.1, Chandrasekeran V.1, Fraser Wares2. Care Seeking Behavior of Chest Symptomatics: A Community Based Study Done in South India after the Implementation of the RNTCP. PLoS ONE | www.plosone.org 2 September 2010 | Volume 5 | Issue 9 |e12379

[9] Thorson A, Hoa N, long N. Health seeking behaviour of individuals with cough of more than three weeks.lancet,2000;356:1823-24.

[10] "Global Tuberculosis Control 2011, WHO, Geneva, 2011, 9 www.who.int/tb/publications/global_report/

[11] TB India 2011 Revised National TB Control Programme Annual Status Report, New Delhi, 2011 www.tbcindia.nic.in/documents.html\# 